\title{
Measurement of Dissipation Factor of Inner Layers of Insulation in Three-Core Belted Cables
}

\author{
Ivan Kostiukov \\ National Technical University "Kharkiv Polytechnic Institute", Kharkiv, Ukraine
}

\author{
Article History \\ Received: \\ 24 March 2021 \\ Accepted: \\ 25 April 2021 \\ Published online: \\ 30 April 2021
}

Keywords

Cross-Correlation;

Electrical Capacitance;

Insulation

Deterioration;

Insulation Testing;

Phase Shift;

Diagnostics of

Power Cables;

Dielectric Power

Losses

\begin{abstract}
This paper presents a substantiation of an approach for direct measurements of dielectric dissipation factor of layers of insulation between the conductors of three-core power cables. Proposed approach is based on grounding of the inspected dielectric layer through the sufficiently low electrical resistance. The results of carried out analysis, which was carried out taking into consideration the presence of numerous parasitic parameters of tested layer of insulation due to the capacitive coupling between the electrically conductive elements of three-core power cable, have shown that for the case of sufficiently low value of used resistor the value of phase shift between the waveforms of voltage drop on inspected layer of insulation and resistor, through which this layer of insulation is grounded, coincides with the value of phase shift between the sine waveforms of current and voltage for parallel equivalent scheme of tested layer of insulation with power losses. Because of the dependence of dielectric power loss angle on the value of phase shift between sine curves of current and voltage, the presented approach for the measurement of dielectric dissipation factor is based on such coincidence of values of phase shift. Depending on the value of applied resistor, the value of dissipation factor is calculated on the basis of measured value of phase shift between the voltage drop on the electrical resistor, through which tested layer of insulation is grounded, and either the waveform of voltage drop on the inspected layer of insulation, or the waveform of applied voltage. Factors that affect the accuracy of measurement are discussed, equivalent schemes of tested three core power cable for various ways of applying testing voltage are presented and the example of practical implementation of presented approach for dissipation factor measurement is also given. Further development of presented approach for dissipation factor measurement is supposed to include the comparative analysis of the results of its practical implementation with the results obtained by applying previously developed techniques based on aggregate measurements.
\end{abstract}

\section{INTRODUCTION}

The problem of inevitable aging of equipment remains extremely actual for various technical applications [1-8]. Many applied issues of electrical engineering which concern the assessment of quality of electrical insulation can be solved by applying the value of dielectric dissipation factor. Because of the dependence on the degree of electrical insulation deterioration and on the quality of manufacturing, the value of dielectric dissipation factor is efficiently used in practice of testing the quality of insulation of rotating electrical machines [9-11], transformers [12], power and communication cables [13, 14] and also for such purposes as the study of process of water trees growing in electrical insulation [15].
In practice of testing the quality of insulation of high voltage power cables measurements of dissipation factor usually are carried out either in a wide range of high (above $1 \mathrm{kV}$ ) values of applied voltage with constant frequency, or by making measurements in a wide range of frequencies, but under a comparatively low (approximately $1 \mathrm{~V}$ ) values of applied voltage. High voltage measurements can be carried out by applying the conventional scheme of Shering bridge [16] or modified amplifier-based scheme of Shering bridge [17], which allows to mitigate the effect of stray capacitance and is suitable for continuous measurements. High voltage measurements allow to make conclusions about the emergence of partial discharges in tested electrical insulation under the certain level of applied voltage [18]. Measurements carried out in a wide range of fre-

Corresponding author: iakostiukow@gmail.com (Ivan Kostiukov)

(C) 2021 The Author(s). Published by O.M. Beketov National University of Urban Economy in Kharkiv

Use permitted under Creative Commons Attribution 4.0 International (CC BY 4.0)

Cite as: Kostiukov, I. (2021). Measurement of dissipation factor of inner layers of insulation in three-core belted cables. Lighting Engineering \& Power Engineering, 60(1), 23-30. https:// doi.org/10.33042/2079-424X.2021.60.1.04 
quencies allow to distinguish several types of dielectric responses which can be used for diagnostic purposes [19].

Carried out in [20] studies have shown distinct benefits of measurements based on the applying of high values of test voltage, made in some range of frequencies, in comparison with measurements which rely on the applying of low values of voltage. Mentioned benefits have been caused by more distinctly obtained voltage dependent permittivity response of tested electrical insulation.

In majority of cases measurements of dissipation factor under the low values of applied voltage are carried out by applying the conventional methods of measurements implemented in modern digital commercially available devices for impedance or immittance measurements [21, 22]. Typical examples are digital immittance meters E7-14 and E7-25 [23], which implement the voltmeter-ammeter method with further selection of active and reactive impedance components by synchronous detection. Other possible suitable methods might be based on the applying of specialized integrated circuits [24], implementation of ellipse approximation algorithms based on the applying of various modifications of the least squares method [25, 26], applying of artificial neural networks [27], auto-balancing bridge method [28] and described in [29] method based on information-filtering demodulation.

Power cables with paper impregnated insulation still constitute a significant portion of the total amount of power cables operating in power systems [30]. Such power cables of low and medium voltage are often manufactured in three phase versions. In this case measurements of dissipation factor are complicated by the presence of several parasitic parameters of tested layer of insulation caused by the capacitive coupling between the adjacent conductive elements of construction.

The individual values of dissipation factor can be estimated by applying described in [31, 32] technique based on aggregate measurements, which implies the estimation of individual values of dissipation factor of any layer of insulation by means of finding the solution of system of linear algebraic equations which establish bonds between the aggregate values of dissipation factor and individual values of electrical capacitances and dissipation factor of layers of insulation for various ways of connection of conductive elements of power cable. However, for such measurements possible inaccuracy of carried out measurements of aggregate values affects the overall accuracy of estimation of dielectric dissipation factor of a particular layer of insulation. This problem is aggravated by the fact that the individual values of electrical capacitance of insulation layers which are used in mentioned system of equations themselves are determined by applying aggregate measurements. In some cases it is possible to determine the individual values of dissipation factor by applying the direct measurements [33]. For this purpose it is possible to use the property of capacitance-to-voltage converters based on operational amplifiers [34], which allows to avoid the undesirable effects caused by the presence of parasitic parameters of tested layer of insulation. However, the direct measurement of individual capacitive parameters of inner layers of insulation of three-core power cables can be accomplished only under pretty strict restrictions that should be imposed on the electrical parameters of parasitic circuits [33]. Therefore, it is preferable to develop a less dependent on parasitic parameters of tested layer of insulation approach for measurements.

\section{MATERIALS AND METHODS}

Three-core belted power cables contain several inner layers of insulation with different values of electrical capacitance and shunt resistance due to the dielectric power losses. Fig. 1 presents the illustration of capacitive coupling in three-core belted cables.

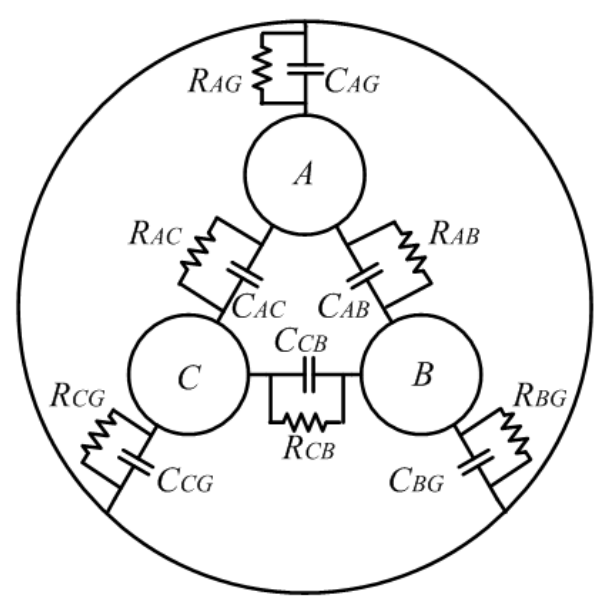

Figure 1. Dielectric parameters of inner insulation layers in three core power cable: $C_{A B}, C_{C B}, C_{A C}$ are the values of electrical capacitance between the conductors, $C_{A G}, C_{C G}$, $C_{B G}$ are the values of electrical capacitance between the sheath and corresponding conductor of power cable, $R_{A B}$, $R_{C B}, R_{A C}$ are the values of shunt resistance caused by power losses in insulation layers between the conductors of power cable, $R_{A G}, R_{B G}, R_{C G}$ are the values of shunt resistance caused by power losses in insulation layers between the conductors and the sheath of power cable

As it can be concluded from the equivalent scheme on Fig. 1, each insulation layer can be characterized by its own electrical capacitance and power loss resistance. These parameters determine the individual values of dissipation factor of corresponding insulation layer between the conductive elements of power cable. In current paper the proposed approach for the measurement of individual 
values of dissipation factor of insulation layers between the conductors of power cable is based on the considered in [31] schemes intended for the estimation of electrical capacitance between the adjacent conductive elements of power cable by applying aggregate measurements. These schemes are presented on Fig. 2.

(a)

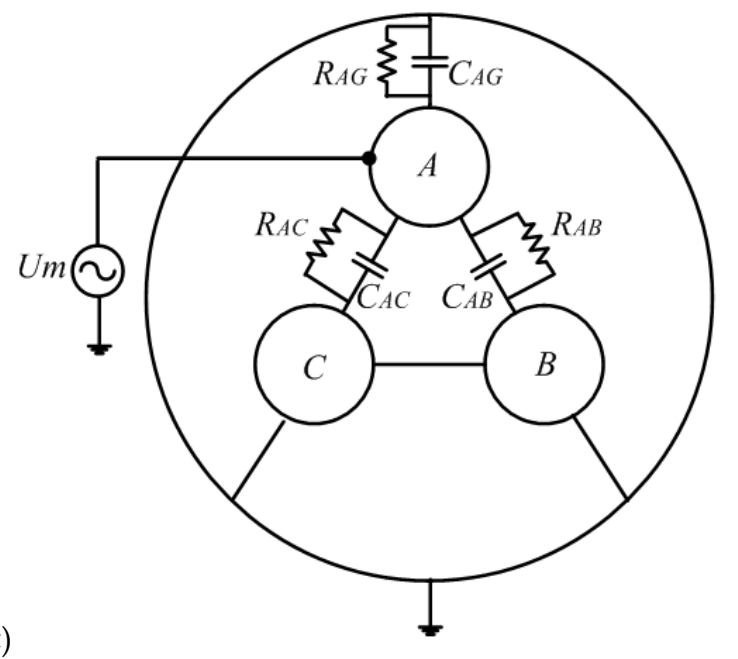

(b)

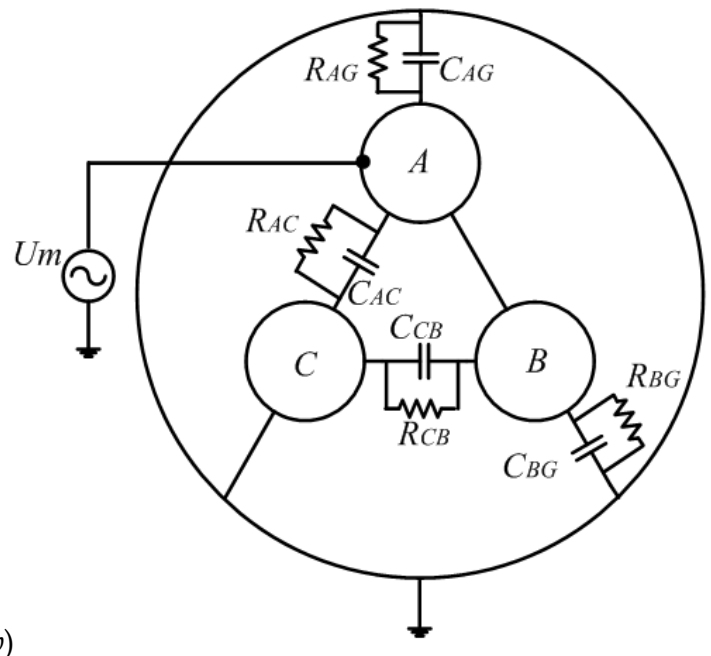

Figure 2. Connection of conductors for getting aggregate values of electrical capacitance: determined by the parameters of 3 insulation layers in power cable $(a)$; determined by the parameters of 4 insulation layers in power cable $(b)$

In this paper the technique for the dissipation factor measurement will be considered with respect to the value of dissipation factor of insulation layer between the conductors $A$ and $C$ on Fig. 1 and Fig. 2 . Considered approach for the direct measurement of dissipation factor is based on presented on Fig. 2 schemes. However, on the contrary to the scheme on Fig. $2 b$, in considered case the inspected layer of insulation is grounded through some electrical resistance with a sufficiently low value. Besides, unlike the scheme presented on Fig. $2 a$, considered case does not imply the presence of connection between the $C$ and $B$ conductors. Such method of connection causes some voltage drop between this con- ductor $C$ and the ground. The existence of this additional voltage drop demands to take into consideration the presence of two additional insulation layers with their electrical capacitance and power loss resistance. The grounding of the conductor $C$ through the low value resistor, as well as the previously mentioned presence of additional parasitic parameters caused by the voltage drop between the conductor $C$ and the ground, is illustrated on Fig. 3.

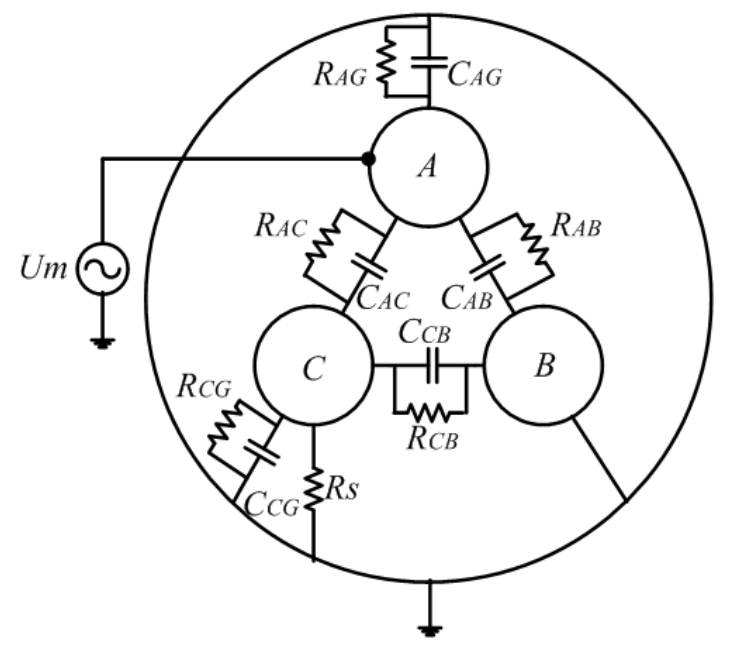

Figure 3. Connection of conductors for the case of direct measurement of dielectric dissipation factor of insulation layer between the $A$ and $C$ conductors

As it can be concluded from the rearranged equivalent circuit presented on Fig. 3 , the equivalent parameters of insulation layers between $A$ and $B$ conductors and between the conductor $A$ and the sheath of power cable are connected in parallel with respect to the electrical capacitance of inspected insulation gap between the conductors $A$ and $C$. Therefore, the value of current, flowing through the part of the equivalent circuit which contains the parameters of inspected insulation layer will depend on the parameters of this insulation gap itself $\left(R_{A C}, C_{A C}\right)$ and also on the value of impedance of the part of equivalent circuit which contains connected in parallel parameters $C_{C G}, R_{C G}, R_{s}, C_{C B}, R_{C B}$. Every single insulation gap in three core power cable presented on Fig. 1 is characterized by its own connected in parallel electrical capacitance, caused by polarization processes, and shunt resistance, caused by the inevitable power losses in insulation. For elementary parallel equivalent circuit of dielectric material with power losses the absolute value of phase shift between the sine curves of current and voltage can be determined as:

$$
\varphi=\arctan \left(\omega C_{p} R_{p}\right),
$$

where $\omega$ is the value of angular frequency of applied voltage, $C_{p}$ is the value of electrical capacitance for parallel equivalent scheme, $R_{p}$ is the value of power loss resistance for parallel equivalent scheme caused by dielectric power losses. Since the value of phase 
shift between sine curves of current and voltage can be calculated by applying (1), the value of dissipation factor can be calculated by applying the following relation:

$$
\tan (\delta)=\tan \left(90^{\circ}-\varphi\right),
$$

where $\delta$ is the value of power loss angle which complements the value of phase shift $\varphi$ up to $90^{\circ}$.

Relations (1) and (2) can be applied to any elementary insulation layer between the conductive elements of power cable. Therefore, accurate technique for the dissipation factor measurement should be able to estimate the value of dissipation factor according to (2), on the basis of previously calculated according to (1) value of phase shift $\varphi$. The value of voltage drop, which is available for direct measurements, on insulation layer between the conductors $A$ and $C$ can be determined as:

$$
U_{1}=\frac{U_{m} R_{A C}\left(j \omega C_{1} R_{1} R_{s}+R_{S}+R_{1}\right)}{j \omega R_{A C} C_{1} R_{1} R_{s}+R_{A C} R_{s}+R_{A C} R_{1}+R_{s} R_{1}+j A},
$$

where $R_{1}$ and $C_{1}$ correspondingly denote the equivalent resistance and capacitance of connected in parallel insulation layers between the $C$ and $B$ conductors and between the conductor $C$ and the grounded sheath of power cable:

$$
\begin{gathered}
R_{1}=\frac{R_{C G} R_{C B}}{R_{C G}+R_{C B}}, \\
C_{1}=C_{C G}+C_{C B}, \\
A=\omega R_{S} R_{1} C_{A C} R_{A C} .
\end{gathered}
$$

The value of voltage drop, on insulation layer between the grounded through $R_{s}$ conductor $C$ and the grounded sheath of power cable can be determined as:

$$
U_{2}=\frac{U_{m} R_{1} R_{s}\left(j \omega C_{A C} R_{A C}+1\right)}{j \omega R_{A C} C_{1} R_{1} R_{S}+R_{A C} R_{S}+R_{A C} R_{1}+R_{S} R_{1}+j A} .
$$

Active and reactive components of $U_{1}$ can be calculated as:

$$
\begin{aligned}
& \operatorname{Re}\left(U_{1}\right)=B_{1}+B_{2}, \\
& \operatorname{Im}\left(U_{1}\right)=B_{3}+B_{4},
\end{aligned}
$$

where $B_{1}, B_{2}, B_{3}, B_{4}$ can be determined as:

$$
\begin{aligned}
& B_{1}=\left(R_{s}+R_{1}\right) U_{m} R_{A C} \times \\
& \times \frac{\left(R_{A C} R_{S}+R_{A C} R_{1}+R_{1} R_{S}\right)}{\left(R_{A C} R_{S}+R_{A C} R_{1}+R_{1} R_{S}\right)^{2}+\left(R_{A C} \omega C_{1} R_{1} R_{S}+A\right)^{2}}, \\
& B_{2}=\omega C_{1} R_{1} R_{S} U_{m} R_{A C} \times \\
& \times \frac{\left(R_{A C} \omega C_{1} R_{1} R_{S}+R_{S} R_{1} \omega C_{A C} R_{A C}\right)}{\left(R_{A C} R_{S}+R_{A C} R_{1}+R_{1} R_{S}\right)^{2}+\left(R_{A C} \omega C_{1} R_{1} R_{S}+A\right)^{2}},
\end{aligned}
$$

$$
\begin{aligned}
& B_{3}=\omega C_{1} R_{1} R_{S} U_{m} R_{A C} \times \\
& \times \frac{\left(R_{A C} R_{S}+R_{A C} R_{1}+R_{1} R_{S}\right)}{\left(R_{A C} R_{S}+R_{A C} R_{1}+R_{1} R_{S}\right)^{2}+\left(R_{A C} \omega C_{1} R_{1} R_{S}+A\right)^{2}},
\end{aligned}
$$

$B_{4}=-\left(R_{S}+R_{1}\right) U_{m} R_{A C} \times$

$$
\times \frac{\left(R_{A C} \omega C_{1} R_{1} R_{S}+R_{S} R_{1} \omega C_{A C} R_{A C}\right)}{\left(R_{A C} R_{S}+R_{A C} R_{1}+R_{1} R_{S}\right)^{2}+\left(R_{A C} \omega C_{1} R_{1} R_{S}+A\right)^{2}},
$$

Active and reactive components of $U_{2}$ can be calculated as:

$$
\begin{aligned}
& \operatorname{Re}\left(U_{2}\right)=B_{5}+B_{6}, \\
& \operatorname{Im}\left(U_{2}\right)=B_{7}+B_{8},
\end{aligned}
$$

where $B_{5}, B_{6}, B_{7}, B_{8}$ can be determined as:

$$
B_{5}=R_{1} R_{s} U_{m} \times
$$$$
\times \frac{\left(R_{A C} R_{S}+R_{A C} R_{1}+R_{1} R_{S}\right)}{\left(R_{A C} R_{S}+R_{A C} R_{1}+R_{1} R_{S}\right)^{2}+\left(R_{A C} \omega C_{1} R_{1} R_{S}+A\right)^{2}},
$$

$B_{6}=\omega C_{A C} R_{1} R_{S} U_{m} R_{A C} \times$

$$
\times \frac{\left(R_{A C} \omega C_{1} R_{1} R_{S}+R_{S} R_{1} \omega C_{A C} R_{A C}\right)}{\left(R_{A C} R_{S}+R_{A C} R_{1}+R_{1} R_{S}\right)^{2}+\left(R_{A C} \omega C_{1} R_{1} R_{S}+A\right)^{2}},
$$

$$
B_{7}=\omega C_{A C} R_{1} R_{s} U_{m} R_{A C} \times
$$$$
\times \frac{\left(R_{A C} R_{S}+R_{A C} R_{1}+R_{1} R_{S}\right)}{\left(R_{A C} R_{S}+R_{A C} R_{1}+R_{1} R_{S}\right)^{2}+\left(R_{A C} \omega C_{1} R_{1} R_{S}+A\right)^{2}},
$$

$B_{8}=-R_{1} R_{s} U_{m} \times$

$\times \frac{\left(R_{A C} \omega C_{1} R_{1} R_{S}+R_{S} R_{1} \omega C_{A C} R_{A C}\right)}{\left(R_{A C} R_{S}+R_{A C} R_{1}+R_{1} R_{S}\right)^{2}+\left(R_{A C} \omega C_{1} R_{1} R_{S}+A\right)^{2}}$.

In general form the relation for the value of phase shift between $U_{2}$ and $U_{1}$ can be determined as:

$$
\varphi_{U 1 U 2}=\arctan \left(\frac{\operatorname{Im}\left(U_{2}\right)}{\operatorname{Re}\left(U_{2}\right)}\right)-\arctan \left(\frac{\operatorname{Im}\left(U_{1}\right)}{\operatorname{Re}\left(U_{1}\right)}\right) .
$$

By taking into consideration (7)-(8), the value of $\varphi_{U 1}$ can be determined as:

$$
\varphi_{U 1}=\operatorname{atan}\left(\frac{g_{1}-g_{2}-g_{3}}{R_{1} R_{s}^{2}+R_{A C} R_{1}^{2}+g_{4}+g_{5}+g_{6}+g_{7}+g_{8}}\right)
$$

where the values of coefficients $g_{1} \ldots g_{8}$ are determined according to:

$$
\begin{aligned}
& g_{1}=\omega C_{1} R_{1}^{2} R_{s}^{2}, \\
& g_{2}=\omega C_{A C} R_{1} R_{S}^{2} R_{A C}, \\
& g_{3}=\omega C_{A C} R_{1}^{2} R_{S} R_{A C}, \\
& g_{4}=2 R_{S} R_{1} R_{A C},
\end{aligned}
$$


$g_{5}=R_{A C} R_{S}^{2}$

$g_{6}=\omega^{2} C_{1}^{2} R_{1}^{2} R_{S}^{2} R_{A C}$,

$g_{7}=R_{1}^{2} R_{S}$,

$g_{8}=\omega^{2} C_{1} R_{1}^{2} R_{S}^{2} R_{A C} C_{A C}$.

By taking into consideration (14)-(15), the value of $\varphi_{U 2}$ can be determined as:

$\varphi_{U 2}=\operatorname{atan}\left(-\frac{g_{9}-g_{10}-g_{11}}{R_{A C} R_{S}+R_{1} R_{A C}+R_{1} R_{S}+g_{12}+g_{13}}\right)$,

where the values of coefficients $g_{9} \ldots g_{13}$ can be determined according to:

$$
\begin{aligned}
& g_{9}=R_{S} R_{1} \omega R_{A C} C_{1}, \\
& g_{10}=R_{S} \omega R_{A C}^{2} C_{A C}, \\
& g_{11}=R_{1} \omega R_{A C}^{2} C_{A C}, \\
& g_{12}=R_{S} R_{1} \omega^{2} C_{A C} R_{A C}^{2} C_{1}, \\
& g_{13}=R_{S} R_{1} \omega^{2} C_{A C}^{2} R_{A C}^{2} .
\end{aligned}
$$

By taking into consideration (21) and (30) the value of phase shift between $U_{2}$ and $U_{1}$ can be determined according to (20). As it can be concluded from the analysis of (21), in case of $R_{s}=0$ the value of $\varphi_{U 1}$ is equal to zero. In this case the relation for $\varphi_{U 2}$ also can be substantially simplified and the absolute value of phase shift between $U_{1}$ and $U_{2}$ determined according to (20) will depend only on the value of power loss resistance and electrical capacitance of insulation layer between the conductors $A$ and $C$ :

$\varphi_{U 1 U 2}=\arctan \left(\omega C_{A C} R_{A C}\right)$.

As the form of (36) coincides with the form of (1), it is easy to infer that grounding of the conductor $C$ through some resistance with negligible value allows to substantially mitigate the influence of parasitic parameters of nearby insulation layers. After the estimation of phase shift $\varphi_{U 1 U 2}$ according to (36) the value of dissipation factor of insulation layer between the $A$ and $C$ conductors can be easily determined by applying similar to (2) relation:

$$
\tan \left(\delta_{A C}\right)=\tan \left(90^{\circ}-\varphi_{U 1 U 2}\right),
$$

where $\delta_{A C}$ is the power loss angle which complements the value of phase shift between the voltage drop on insulation layer between the conductors $A$ and $C$ and current which flows through this insulation layer, up to $90^{\circ}$. However, the decreasing of $R_{s}$ leads to the decreasing of voltage drop $U_{2}$. Such decreasing complicates measurements as it will obviously degrade their noise stability. This problem partially can be solved either by the increasing of the value of test voltage $U_{m}$, or by gaining $U_{2}$ by applying appropriate amplifying circuits. In practice it is impossible to reduce the value of $R_{\mathrm{S}}$ down to zero, as according to (6) in this case the value of voltage drop $U_{2}$ also will be diminished down to zero and the result of the direct measurement of $U_{1}$ will coincide with the value of test voltage $U_{m}$. The necessity of keeping the value of $R_{\mathrm{S}}$ at levels which will provide the ability for the direct measurements of $U_{2}$ leads to some inaccuracy in estimated value of dissipation factor, as for the case of $U_{2} \neq 0$ the value of initial phase of $U_{1}$ also differs from zero and the value of phase shift $\varphi_{U 1 U 2}$ determined according to (19), will not reflect accurately the dielectric properties of insulation layer between the conductors $A$ and $C$. Consequently, the proposed approach for the dissipation factor measurement implies:

- grounding of the inspected layer of insulation through the low value resistance. Sufficiently low value of resistance implies that the value of voltage drop on this resistor and connected in parallel corresponding elements of scheme caused by the capacitive coupling between the adjacent conductive elements should be negligible in comparison with the value of applied voltage;

- measurement of $\varphi_{U 1}$ and $\varphi_{U 2}$;

- calculation of phase shift $\varphi_{U 1 U 2}$ between the values of voltage drop on inspected layer of insulation and $R_{s}$. For the case if the value of $\varphi_{U 1}$, due to the sufficiently low value of $R_{\mathrm{S}}$, is considered to be negligible, estimation of $\varphi_{U 1 U 2}$ can be carried out on the basis of measured value of $\varphi_{U 2}$, i.e. in this case it is possible to assume that $\varphi_{U 1 U 2}$ is approximately equal to $\varphi_{U 2} ;$

- calculation of dissipation factor according to (37).

Measurement of $\varphi_{U 1}$ and $\varphi_{U 2}$ can be carried out by applying the presented on Fig. 4, 5 schemes.

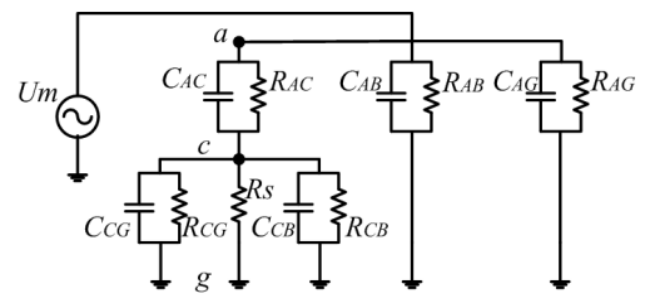

Figure 4. The applying of testing voltage for the measurements of phase of voltage drop $\varphi_{U 2}$

As it can be concluded from Fig. 4, the value of Qu2 should be measured as the value of phase shift between the applied to the tested cable voltage $U_{m}$ and the value of voltage drop on $R_{\mathrm{S}}$ i.e. between the values of voltage drop across the points $a g$ and $c g$ on Fig. 4. Measurement of $\varphi_{U 1}$ implies the inverse applying of voltage and is carried out by means of making measurements of the value of phase shift between $U_{m}$ and the value of voltage drop across the points $c g$ on Fig. 5 . 


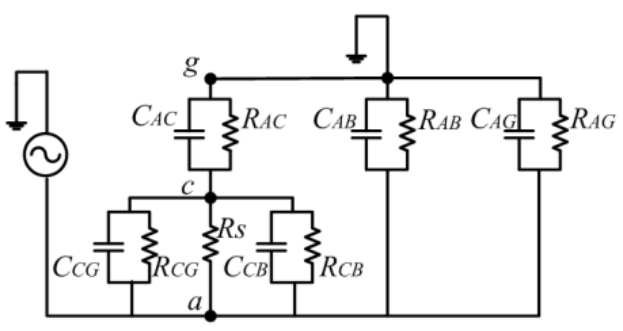

Figure 5. The applying of testing voltage for the measurements of phase of voltage drop $\varphi_{U 1}$

\section{RESULTS OF PRACTICAL IMPLEMENTATION AND DISCUSSION}

Practical implementation of proposed approach for the estimation of dissipation factor has been carried out by measuring the values of dissipation factor of insulation layers between the conductors in a 3 core power cable with paper impregnated insulation after its 26 years of operation on a nuclear power plant. The value of phase shift between the values of voltage drop on tested layer of insulation and additional resistor $R_{S}$ has been calculated by applying the conventional cross-correlation method. According to mentionedmethod the value of phase shift between two sine curves can be calculated according the following relation [35]:

$\varphi=\arccos \left(\frac{R_{U 1 U 2}}{\sqrt{R_{U 1} R_{U 2}}}\right)$,

where $R_{U 1 U 2}$ denotes the value of cross-correlation function between the analyzed sine curves, $R_{U 1}$ and $R_{U 2}$ correspondingly denote the values of autocorrelation functions of analyzed signals.

The values of autocorrelation functions $R_{U 1}$ and $R_{U 2}$, as well as the value of $R_{U 1 U 2}$, have to be calculated for zero values of their lag time. The frequency of applied voltage was equal to $1000 \mathrm{~Hz}$. The value of $R_{s}$ was selected equal to $994 \mathrm{Ohm}$. All calculations have been carried out under the assumption of negligible impact of $\varphi_{U 1}$ on the estimated value of dissipation factor. Fig. 6 presents typical voltage waveforms which have been obtained in order to carry out calculation of phase shift according to (38).

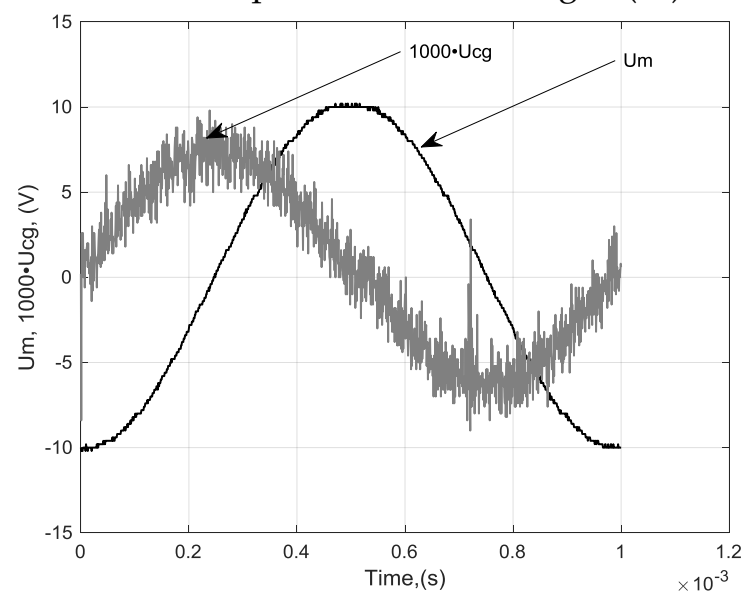

Figure 6. An example of analyzed waveforms of voltage
Fig. 6 also illustrates previously mentioned degrading of noise stability of measurements caused by the desire of eliminating the affect of $\varphi_{U 1}$ on the accuracy of carried out estimation by keeping the value of $R_{s}$ at sufficiently low values, which eventually results in undesirable distortions of voltage drop between the points $c$ and $g$ on Fig. 4 and Fig. 5 by noise components.

The results of carried out measurements are presented in Table 1.

Table 1. The results of carried out measurements

\begin{tabular}{ccc}
\hline $\begin{array}{c}\text { Layer of insulation } \\
\text { between the conductors }\end{array}$ & $\varphi_{22}{ }^{\circ}$ & $\begin{array}{c}\text { Dissipation } \\
\text { factor, \% }\end{array}$ \\
\hline$A C$ & 89.24 & 1.33 \\
$A B$ & 89.22 & 1.36 \\
$B C$ & 89.08 & 1.60
\end{tabular}

Taking into consideration that all measurements have been carried out by applying values of voltage whish are significantly lower than the values of voltage that affect the insulation of such cables under the normal conditions of operation and also possible increasing of dissipation factor due to the presence of partial discharges, obtained under the impact of significantly lower voltage values of dissipation factor presented in Table 1 can considered to be pretty high. The reason for calculated high values of dielectric dissipation factor also can be caused by its frequency dependence.

\section{CONCLUSIONS}

The values of dissipation factor of inner insulation layers in three core belted cables can be estimated by means of consecutive grounding of cores of tested power cable through the resistance with a sufficiently small value, followed by further measurement of phase shift between the values of voltage drop on the inspected layer of insulation and the values of voltage drop on this electrical resistance. Such grounding inevitably leads to the emergence of additional parasitic paths for current flow caused by the capacitive coupling between the grounded through this resistor core and other grounded elements of power cable. However, for the case of sufficiently low value of used resistance the effect of these parasitic elements of measurement scheme can considered to be negligible.

\section{DISCLOSURE STATEMENT}

No potential conflict of interest was reported by the author(s).

\section{REFERENCES}

1. Fawad, M., \& Iqbal, M. (2020). Electrical and environmental aging of modern cable insulation. International Journal of Engineering Research E Technology, 89(9), 929-936. 
2. Nie, H., Wei, X., Wang, Y., \& Chen, Q. (2018). A study of electrical aging of the turn-to-turn oil-paper insulation in transformers with a step-stress method. Energies, 11(12), 3338. https:/ / doi.org/10.3390/en11123338

3. Shutenko, O., \& Kulyk, O. (2020). Analysis of gas content in oil-filled equipment with defects for which ethane is the key gas. Lighting Engineering \& Power Engineering, 2(58), 33-42. https://doi.org/10.33042/2079-424X $-2020-2-58-33-42$

4. Cazacu, E., Ionita, V., \& Petrescu, L. (2018). Thermal aging of power distribution transformers operating under nonlinear and balanced load conditions. Advances in Electrical and Electronic Engineering, 16(1), 92-100. https://doi.org/10.15598/aeee.v16i1.2701

5. Kostiukov, I. (2021). Particular properties of estimation of partial capacitances of insulation of three core power cables by applying aggregate measurements. Ukrainian Metrological Journal, 1, 15-20. https://doi.org/ 10.24027/2306-7039.1.2021.228201 (in Ukrainian)

6. Xie, J., Dong, M., Yu, B., Hu, Y., Yang, K., \& Xia, C. (2020). Physical model for frequency domain spectroscopy of oil-paper insulation in a wide temperature range by a novel analysis approach. Energies, 13(17), 4530. https:// doi.org/10.3390/en13174530

7. Kostiukov, I. (2021). The analysis of some results of electrical capacitance and dissipation factor measurements. In 2021 2nd International Conference on Robotics, Electrical and Signal Processing Techniques (ICREST) (pp. 510-514). IEEE. https://doi.org/10.1109/ICREST51555. 2021.9331065

8. Trunova, I., Myroshnyk, O., \& Pazy, V. (2018). Analysis of the application of methods for evaluation of technical state of distribution networks. Lighting Engineering \& Power Engineering, 2(52), 54-58. https://doi.org/10. 33042/2079-424X-2018-2-52-54-58 (in Ukrainian)

9. Farahani, M., Borsi, H., \& Gockenbach, E. (2007). Study of capacitance and dissipation factor tip-up to evaluate the condition of insulating systems for high voltage rotating machines. Electrical Engineering, 89(4), 263-270. https://doi.org/10.1007/s00202-006-0011-9

10. Bezprozvannych, G.V., \& Roginskiy, A.V. (2018). Dielectric spectroscopy of casing thermosetting composite electrical insulation system of induction traction electric machines. Electrical Engineering \& Electromechanics, 1, 1720. https:/ / doi.org/10.20998/2074-272X.2018.1.02

11. Younsi, K., Neti, P., Shah, M., Zhou, J.Y., Krahn, J., Weeber, K., \& Whitefield, C.D. (2010). On-line capacitance and dissipation factor monitoring of AC stator insulation. IEEE Transactions on Dielectrics and Electrical Insulation, 5(17), 1441-1452. https://doi.org/10.1109/TDEI.2010.559 5545

12. Onal, E. (2012). A study for examining dissipation factors of various insulations and test transformers in the wide range of frequency. Elektronika ir Elektrotechnika, 121(5), 27-32. https:// doi.org/10.5755/j01.eee.121.5.1647

13. Fothergill, J.C., Dodd, S.J., Dissado, L.A., Liu, T., \& Nilsson, U.H. (2011). The measurement of very low conductivity and dielectric loss in XLPE cables: a possible method to detect degradation due to thermal aging. IEEE Transactions on Dielectrics and Electrical Insulation, 18(5), 1544-1553. https:/ / doi.org/10.1109/TDEI.2011.6032823
14. Bezprozvannych, G.V., \& Mirchuk, I.A. (2017). The evaluation of possibility of normal operation of cables based on twisted pairs with PVC jacket under the conditions of high humidity and temperature. Electrical Engineering $\mathcal{E}$ Electromechanics, 5, 51-54. https://doi.org/10. 20998/2074-272X.2017.5.08

15. Ozaki, T., Ito, N., Nakamura, S., \& Kawai, J. (2003). Changes in capacitance and dielectric dissipation factor of water-treed XLPE with applied voltage. Electrical Engineering in Japan, 144(1), 12-20. https://doi.org/10.1002/ eej. 10160

16. Kornhuber, S., Markalous, S., Muhr, M., Strehl, T., \& Sumereder, C. (2009). Comparison of methods for the dissipation factor measurement at practical examples. In Proceedings of the $16^{\text {th }}$ International Symposium on High Voltage Engineering (p. C-43). SAIEE.

17. Bera, S.C., \& Chattopadhyay, S. (2003). A modified Schering bridge for measurement of the dielectric parameters of a material and the capacitance of a capacitive transducer. Measurement, 33(1), 3-7. https://doi.org/10. 1016/S0263-2241(02)00040-4

18. Eigner, A., \& Rethmeier, K. (2016). An overview on the current status of partial discharge measurements on AC high voltage cable accessories. IEEE Electrical Insulation Magazine, 32(2), 48-55. https:/ / doi.org/10.1109/MEI. 2016.7414231

19. Werelius, P., Tharning, P., Eriksson, R., Holmgren, B., \& Gafvert, U. (2001). Dielectric spectroscopy for diagnosis of water tree deterioration in XLPE cables. IEEE Transactions on Dielectrics and Electrical Insulation, 8(1), 2742. https:// doi.org/10.1109/94.910423

20. Pedersen, K., Sedding, H., Fenger, M., Holboell, J., \& Henriksen, M. (2006). Laboratory results from dielectric spectroscopy of field aged XLPE cables with respect to water trees. In Conference Record of the 2006 IEEE International Symposium on Electrical Insulation (pp. 509-514). IEEE. https:/ / doi.org/10.1109/ELINSL.2006.1665368

21. Morsalin, S., Phung, B.T., \& Danikas, M.G. (2018). Influence of partial discharge on dissipation factor measurement at very low frequency. In 2018 Condition Monitoring and Diagnosis (CMD) (pp. 1-5). IEEE. https:// doi.org/ 10.1109/CMD.2018.8535721

22. Bergman, A. (2018). Achievable accuracy in industrial measurement of dissipation factor of power capacitors. NCSLI Measure, 12(1), 34-41. https://doi.org/10. 1080/19315775.2017.1335585

23. Trushakov, D., Rendzinyak, S., \& Vasylchyshyn, I. (2014). Determining of complex magnetic permeability of the ferromagnetic material by complex impedance of inductance coil with ferromagnetic core. Przeglad Elektrotechniczny, 90(4), 221-223. https://doi.org/10.12915/pe. 2014.04.53

24. Chabowski, K., Piasecki, T., Dzierka, A., \& Nitsch, K. (2015). Simple wide frequency range impedance meter based on AD5933 integrated circuit. Metrology and Measurement Systems, 22(1), 13-24. https://doi.org/10.1515/ mms-2015-0006

25. Ramos, P.M., Janeiro, F.M., Tlemçani, M., \& Serra, A.C. (2009). Recent developments on impedance measurements with DSP-based ellipse-fitting algorithms. IEEE 
Transactions on Instrumentation and Measurement, 58(5), 1680-1689. https://doi.org/10.1109/TIM.2009.2014512

26. Ramos, P.M., \& Janeiro, F.M. (2007). Implementation of DSP based algorithms for impedance measurements. In 2007 IEEE International Conference on Signal Processing and Communications (pp. 816-819). IEEE. https:// doi.org/10.1109/ICSPC.2007.4728444

27. Roj, J., \& Cichy, A. (2015). Method of measurement of capacitance and dielectric loss factor using artificial neural networks. Measurement Science Review, 15(3), 127131. https://doi.org/10.1515/msr-2015-0019

28. Dumbrava, V., \& Svilainis, L. (2007). The automated complex impedance measurement system. Elektronika ir Elektrotechnika, 76(4), 59-62.

29. Sun, S., Xu, L., Cao, Z., Zhou, H., \& Yang, W. (2014). A high-speed electrical impedance measurement circuit based on information-filtering demodulation. Measurement Science and Technology, 25(7), 075010. https://doi.org/10.1088/0957-0233/25/7/075010

30. Korzhov, A.V. (2018). Effect of magnetic field on partial discharge parameters in power cables and on the breakdown characteristics of impregnated paper insulation. Journal of Electrostatics, 96, 169-176. https:/ / doi.org/ 10.1016/j.elstat.2018.11.001
31. Moskvitin, E.S. (2011). Control of aging processes of power cables with paper impregnated insulation by measurements of dielectric properties of insulation layers. Bulletin of National Technical University "KhPI", 3, 95-106. (in Russian)

32. Bezprozvannych, G.V. (2008). Dielectric scanning of the transverse structure of multicore cables using the aggregate measurement method. Technical Electrodynamics, 3, 30-36. (in Russian)

33. Naboka, B.G., Bezprozvannych, G.V., Stangei, A.S., \& Radchenko, O.N. (2005). Method of direct measurements of partial capacitances of multicore cables. Bulletin of National Technical University "KhPI", 42, 80-86. (in Russian)

34. Liao, M.Y., Tian, Y., \& Wang, K.H. (2010). Microcapacitance measurement based on phase-sensitive detection. In 2010 Third International Symposium on Information Science and Engineering (pp. 375-378). IEEE. https://doi. org/10.1109/ISISE.2010.42

35. Liu, Y.Z., \& Zhao, B. (2015). Phase-shift correlation method for accurate phase difference estimation in range finder. Applied Optics, 54(11), 3470-3477. https:// doi.org/ 10.1364/AO.54.003470

\title{
Вимірювання тангенса кута діелектричних втрат внутрішніх шарів ізоляції в трьохжильних кабелях $з$ поясною ізоляцією
}

\author{
Іван Костюков
}

Анотація. В статті представлено обгрунтування підходу до прямого вимірювання тангенса кута діелектричних втрат шарів ізоляції між жилами трьохжильних силових кабелів. Запропонований підхід заснований на заземленні досліджуваного шару ізоляції через достатньо низький електричний опір. Результати аналізу, проведеного з урахуванням наявності численних паразитарних параметрів досліджуваного шару ізоляції внаслідок ємнісних зв'язків між електропровідними елементами конструкції трьохжильного силового кабелю, показали, що для випадку достатньо низького значення електричного опору використаного резистора значення фазового зсуву між напругою на досліджуваному шарі ізоляції та резисторі, через який цей шар ізоляції заземлено, збігається зі значенням фазового зсуву між синусоїдальними кривими струму та напруги для паралельної схеми заміщення досліджуваного шару ізоляції 3 діелектричними втратами. Внаслідок залежності кута діелектричних втрат від величини фазового зсуву між струмом та напругою, представлений підхід до вимірювання тангенса кута діелектричних втрат базується на зазначеному збігу значень фазового зсуву. В залежності від величини використаного резистора, значення тангенса кута діелектричних втрат обчислюється на основі виміряного значення фазового зсуву між падінням напруги на електричному резисторі, через який заземлено досліджуваний шар ізоляції, та між падінням напруги на досліджуваному шарі ізоляції, або між прикладеною до силового кабелю напругою. В статті також обговорено фактори, що впливають на точність вимірювань, запропоновано схеми заміщення досліджуваного трьохжильного силового кабелю для випадку різних способів подачі випробувальної напруги та наведено приклад практичної реалізації представленого підходу для вимірювання тангенса кута діелектричних втрат. Подальший розвиток представленого підходу до вимірювання тангенса кута діелектричних втрат повинен містити порівняльний аналіз результатів його практичної реалізації з результатами, отриманими шляхом застосування раніше розроблених та заснованих на сукупних вимірюваннях методик.

Ключові слова: взаємна кореляція, електрична ємність, старіння ізоляції, випробування ізоляції, фазовий зсув, діагностика силових кабелів, діелектричні втрати.

\section{NOTES ON CONTRIBUTORS}

Ivan Kostiukov

iakostiukow@gmail.com
Ph.D., Assosiate Professor

Department of Electrical Isolation and Cable Engineering

National Technical University "Kharkiv Polytechnic Institute", Kharkiv, Ukraine

(iD) https:// orcid.org/0000-0002-8923-0579

p https://publons.com/researcher/ABG-6080-2020/

C https:// scopus.com/authid/ detail.uri?authorId=57220864135 